\title{
Polymorphisms in $L E P$ and NPY genes modify the response to soluble fibre Plantago ovata husk intake on cardiovascular risk biomarkers
}

\author{
Anna Crescenti • Rosa Solà • Rosa M. Valls • \\ Anna Anguera • Lluís Arola
}

Received: 27 October 2011 / Accepted: 18 May 2012/Published online: 6 June 2012

(C) Springer-Verlag 2012

\begin{abstract}
The satiating effect of fibre consumption has been related to gut hormones, such as peptide YY and leptin. These peptides may also influence cardiovascular (CVD) risk biomarkers. Nevertheless, there is wide interindividual variation in metabolic responses to fibre consumption. The objective was to investigate differences in the effects of soluble fibre, in the form of Plantago ovata husk (Po-husk) treatment, on CVD risk biomarkers according to selected polymorphisms in genes related to satiety. The study was a multi-centred, double-blind, placebo-controlled, parallel and randomised trial in mildmoderate hypercholesterolaemic patients (age range: 43-67 years). Eight polymorphisms in three genes related to satiety (LEP, NPY and $P Y Y$ ) were identified in 178 participants; 88 patients in the placebo (microcrystalline cellulose $14 \mathrm{~g} /$ day) group and 90 in the Po-husk (14 g/day) group, which had added to a low-saturated-fat diet for 8 weeks. The CVD biomarkers measured included the following: lipid profile, blood pressure (BP), glucose, insulin, hs-CRP, oxidised LDL and IL-6. Relative to the placebo, Po-husk consumption lowered the plasma total cholesterol concentration by $3.3 \%$ according to rs 7799039
\end{abstract}

\footnotetext{
A. Crescenti · L. Arola ( $\square)$

Departament de Bioquímica i Biotecnologia, Centre Tecnològic

de Nutrició i Salut (CTNS), TECNIO, CEICS, Universitat

Rovira i Virgili, Campus Sescelades. Marcel-lí Domingo,

s/n, 43007 Tarragona, Spain

e-mail: 1luis.arola@urv.cat

R. Solà · R. M. Valls

Unitat de Recerca en Lípids i Arteriosclerosi, CIBERDEM, Hospital Universitari Sant Joan de Reus, IISPV, Universitat Rovira i Virgili, Reus, Spain

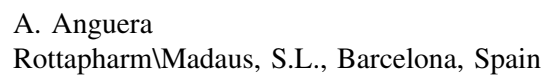

polymorphism in the $L E P$ gene $(p<0.05)$. Furthermore, the Po-husk reduced systolic BP (mean [95\% CI]) by $-8 \mathrm{mmHg}(-14.16 ;-1.90)$ and hs-CRP by $24.9 \%$ in subjects with the AA genotype of the rs 16147 polymorphism in the NPY gene ( $32 \%$ of our total population; $p<0.05$ ), which remained significant after Bonferroni correction. In conclusion, polymorphisms in the LEP and NPY genes potentiate the response to Po-husk, particularly the effects on systolic BP and the hs-CRP plasma concentration.

Keywords Anorexigenic peptides - Cardiovascular disease $\cdot$ Fibre $\cdot$ Polymorphisms

\section{Introduction}

Dietary fibre is a collective term for a variety of plant substances that are resistant to digestion by human gastrointestinal enzymes. Dietary fibres can be classified into two majors groups depending on their solubility in water. In humans, the structural or matrix fibres (lignins, cellulose and some hemicelluloses) are insoluble, whereas the natural gel-forming fibres (pectins, gums, mucilages and the remainder of the hemicelluloses) are soluble (Theuwissen and Mensink 2008). Plantago ovata husk (Po-husk) is a source of natural, concentrated, soluble fibre. Several studies have shown that the consumption of soluble fibre such as Po-husk reduces the risk of developing cardiovascular disease (CVD) through reduction in total cholesterol (TC) and low-density lipoprotein cholesterol (LDL-C) levels (Brown et al. 1999; Theuwissen and Mensink 2008; Anderson et al. 2009; Queenan et al. 2007). Moreover, it has been shown that soluble fibre is more effective in lowering blood cholesterol and LDL-C concentrations than insoluble fibre (Brown et al. 1999; Vuksan et al. 2011; 
Fernandez 2001; Jenkins et al. 2000; Solà et al. 2007). Soluble fibre has also been shown to reduce other CVD risk biomarkers such as triglyceridaemia (Solà et al. 2010; Galisteo et al. 2010), blood glucose levels (Ziai et al. 2005; Sierra et al. 2002), arterial hypertension (He et al. 2004; Galisteo et al. 2005) and systolic blood pressure (Solà et al. 2010).

Studies with humans and animals have shown that soluble fibre consumption is associated with altered circulating levels of the anorexigenic gut hormone peptide YY (PYY) (Beck 2010; Karhunen et al. 2010; Vitaglione et al. 2009) and of the adipocyte-released anorexigenic peptide leptin (Young et al. 2012; Artiss et al. 2006). Furthermore, it has been demonstrated that PYY and leptin act on the hypothalamus, influencing the expression of some central signals such as the orexigenic peptide neuropeptide $\mathrm{Y}$ (NPY) (Roux and Bloom 2005; Batterham et al. 2002; Jequier 2002).

Many studies suggest that PYY, leptin and NPY might also be related to CVD risk biomarkers. For instance, NPY has been linked with blood pressure (BP) (Baltatzi et al. 2008), PYY has been associated with glucose metabolism and insulin resistance (Boey et al. 2007; Ukkola et al. 2011), and leptin may have multiple effects on lipid metabolism (Lago et al. 2009).

The effect of diet on human health and disease is affected by differences in genetic background (Simopoulos 2010). However, the possible interactions between soluble fibre consumption and an individual's genetic variability have rarely been studied. Furthermore, many of the genes that have been studied are related to lipid metabolism, such as apo E, apo A1 and fatty acid-binding protein 2 (FABP2) (Torres et al. 2009; Wu et al. 2007; Solà et al. 2007).

Several studies have described polymorphisms in LEP (leptin), $N P Y$ and $P Y Y$ genes, and these genetic variations have been related to their expression levels and plasma concentrations (Itokawa et al. 2003; Hoffstedt et al. 2002). Interestingly, these polymorphisms have also been associated with CVD risk factors, such as obesity (Torekov et al. 2005; Ma et al. 2005), plasma lipids (Salminen et al. 2008) and BP (Ilveskoski et al. 2008). These associations might indicate that polymorphisms in the $L E P, N P Y$ and $P Y Y$ genes can modify the beneficial effect of fibre consumption on CVD risk biomarkers.

The aim of this study was to assess the effect of various polymorphisms in the $P Y Y, N P Y$ and $L E P$ genes on the behaviours of CVD risk biomarkers, such as TC, LDL-C, high-density lipoprotein cholesterol (HDL-C), triglycerides (TG), apolipoprotein (Apo), insulin, oxidation and inflammation biomarker concentrations in the plasma, insulin resistance and $\mathrm{BP}$, in combination with the consumption of soluble fibre $(14 \mathrm{~g} /$ day for 8 weeks $)$ from the husk of Plantago ovata (Po-husk).

\section{Subjects and methods}

Study design and population

The population studied was selected from a previous study (Solà et al. 2010). The study design and population have previously been described (Solà et al. 2010). Briefly, the two-arm study was a phase IV-II, multi-centred, randomised, double-blind, placebo-controlled analysis of the effect of Po-husk on hypercholesterolaemia.

The participants were recruited between September 2005 and June 2007 and consisted of men and women more than 20 years of age, with LDL-C $\geq 3.35 \mathrm{mmol} / \mathrm{L}$ and $\leq 4.88 \mathrm{mmol} / \mathrm{L}$, as well as at least one other major cardiovascular risk factor (age $>45$ years in men and $>55$ years in women, a smoking habit, high BP, HDL-C $\leq 1.03 \mathrm{mmol} / \mathrm{L}$ in men and $\leq 1.19 \mathrm{mmol} / \mathrm{L}$ in women, or a family history of premature heart disease). Exclusion criteria included diabetes mellitus, any other chronic disease, hypolipaemic treatment, TG $>3.97 \mathrm{mmol} / \mathrm{L}, \mathrm{BMI}>35 \mathrm{~kg} /$ $\mathrm{m}^{2}$ and a history of cardiovascular disease. All participants provided written informed consent prior to enrolment in the trial.

The randomisation code was computer generated. Participant assignment to the treatment or the placebo arm was at a ratio of 1:1. The number sequence for the subject, centre and treatment assignment were allocated via an interactive electronic response system by the Barcelona Randomisation Unit.

Of the participants considered potentially eligible, 209 were included in the study. After a 2 -week run-in period with $10-13 \%$ of saturated fatty acids (SFA) in the diet, these patients were randomly assigned to receive $(n=101$; 45 men/56 women) the Po-husk (Plantaben ${ }^{\circledR}$, Madaus S.A., Barcelona, Spain) treatment (14 g/day) or $(n=108 ; 46$ men/62 women) a placebo (microcrystalline cellulose; $14 \mathrm{~g} /$ day) for 8 weeks. Blinding was maintained using matching placebo sachets that did not differ from the active fibre with respect to colour, appearance, or any other physical characteristic.

Po-husk was manufactured as a palatable, orange-flavoured, sugar-free product and was distributed in 4 sachets of $5 \mathrm{~g}$ each (70\% soluble fibre). The dosage was one sachet dissolved in $200 \mathrm{~mL}$ of water, taken $15 \mathrm{~min}$ before breakfast and lunch and two sachets before dinner.

During the intervention period, the percentage of saturated fatty acids (SFA) in the diet was set at $\leq 7 \%$ within an isocaloric diet. At each of four clinical visits, diet compliance was monitored using 3-day dietary records and interviews with the dietician. On occasions, the participants were contacted by telephone without warning and invited to fill-in a 24-h dietary recall. In each visit, standard anthropometric data were obtained while participants were 
wearing lightweight clothing and no shoes. Participants were controlled to maintain their weight and were advised to maintain their usual physical activity.

The study was approved by the Clinical Research Ethical Committees of all participating centres as well as the AEMPS (Spanish Medicines Agency). This study was conducted according to the guidelines laid down in the Declaration of Helsinki. This trial was registered with CinicalTrials.gov, number NCT00502047, and EudraCT No. year-2004-002184-24.

\section{Biological samples and measurements}

Details of the blood collection and biomarker measurements have been published (Solà et al. 2010) and will be presented briefly here. A fasting blood sample was taken at baseline and at week 8 to measure safety and efficacy data. The biomarkers measured were the following: BP, serum TC, TG, HDL-C, ApoA-1, ApoB-100, high sensitivity C-reactive protein (hs-CRP) and glucose, using standard methods on an autoanalyser (Beckman Coulter-Synchron, Galway, Ireland), and interleukin 6 (IL-6) and ultrasensitive insulin by another autoanalyser (Beckman CoulterAccess Immunoassay Systems, Galway, Ireland). ELISA kits were used to measure plasma oxidised LDL (oxLDL) (Mercodia AB, Uppsala, Sweden), vascular adhesion molecule-1 (VCAM-1) and intercellular adhesion molecule-1 (ICAM-1) (R\&D Systems, Minneapolis, USA). For each participant, LDL-C was calculated by means of the Friedewald formula (Friedewald et al. 1972) and insulin resistance was calculated by the HOMA index (Matthews et al. 1985).

DNA isolation, SNP selection and genotyping

Genomic DNA from each subject was isolated from peripheral blood leucocytes using a cell package commercial kit (Servicios Hospitalarios, Spain). Polymorphisms in genes encoding proteins that exert or mediate anorexigenic effects and that has been related to CVD risk biomarkers were selected. We included only polymorphisms whose existence in Caucasian populations is documented according to literature data or publicly available databases. To ensure a wide number of subjects who are homozygous for the rare alleles, we selected only those polymorphisms with a minor allele frequency in Europeans of at least $10 \%$, as indicated by the single-nucleotide polymorphisms (SNP) public database (dbSNP; http:// www.ncbi.nlm.nih.gov/SNP). Moreover, only polymorphisms that were previously associated with relevant phenotypes, such as body mass index and body composition, or with gene expression levels were considered. This resulted in the selection of the following eight polymorphisms in three genes (Table 1): the $-1,746 \mathrm{~A}>\mathrm{G}(\mathrm{rs} 2070592) \mathrm{SNP}$ in the promoter region, the IVS $3+68 \mathrm{C}>\mathrm{T}(\mathrm{rs} 162430)$ SNP in intron 3, and the $215 \mathrm{G}>\mathrm{C}$ SNP (rs1058046) resulting in the non-synonymous amino acid substitution Arg72Thr, of the $P Y Y$ gene; the $-485 \mathrm{C}>\mathrm{T}$ SNP (rs16147) and the $-883 \mathrm{TG}$ ins/del polymorphism (rs3037354) in the promoter region, and the coding-synonymous Ser68Ser (rs5574) SNP, of the NPY gene; and the $-2548 \mathrm{G}>\mathrm{A}(\mathrm{rs} 7799039)$ and the $19 \mathrm{G}>\mathrm{A}(\mathrm{rs} 2167270)$ SNPs in the promoter region of the LEP gene. The eight polymorphisms were analysed by Iplex Gold Sequenom technology (coordinacion.cegen@upf.edu).

\section{Statistical analyses}

Deviation from Hardy-Weinberg equilibrium for genotype frequencies at individual loci was assessed using standard Chi-squared tests.

Continuous descriptive variables are expressed as the means \pm standard deviations (SD), while genotype and allele frequencies are expressed as percentages. To compare the means of descriptive variables between treatment groups, an analysis of covariance was used (ANCOVA) for the continuous variables and the Fisher's exact test was used for the categorical variables. Student's $t$ test was used to analyse the association of polymorphisms with baseline variables, and this was confirmed by ANCOVA with individual baseline variables as dependent variables and with polymorphisms and covariates, determined by stepwise regression (successive steps), as independent variables.

To study the treatment response differences according to genotypes, we calculated the efficacy variable as it changed from baseline to week 8 . Observations with missing data were excluded from the analysis. The results are expressed as baseline-adjusted least-square means and $95 \%$ confidence intervals $(95 \% \mathrm{CI})$ for each genotype and treated group. Polymorphisms that were associated with baseline variables were selected for the analysis. ANCOVA was used for all the analysis with the efficacy variable as the dependent variable and treatment, baseline values and covariates included in the model. Independent variables (covariates) were determined by stepwise regression (successive steps). Non-normally distributed variables were tested with a non-parametric Kruskal-Wallis test. We performed subgroups analysis by genotype categories with polymorphisms that showed an interaction with treatment on efficacy variables.

Analyses were performed under the recessive, dominant, overdominant and codominant models. Statistical significance was considered at $p<0.05$. We applied Bonferroni correction, to correct for multiple testing, by considering the number of studied genes for each efficacy variable. 
Table 1 Description of polymorphisms selected

\begin{tabular}{llll}
\hline Gene & SNP ID & Location & Codon or nucleotide change \\
\hline$L E P$ & rs7799039 & $5^{\prime}$ flanking region/promoter & $-2,548 \mathrm{G}>\mathrm{A}$ \\
& rs2167270 & $5^{\prime}$ flanking region/promoter & $19 \mathrm{G}>\mathrm{A}$ \\
$P Y Y$ & rs1058046 & Exon 3 & Arg72Thr \\
& rs162430 & Intron 3 & $68 \mathrm{C}>\mathrm{T}$ \\
& rs2070592 & $5^{\prime}$ flanking region/promoter & $-1,746 \mathrm{~A}>\mathrm{G}$ \\
& rs16147 & $5^{\prime}$ flanking region/promoter & $-485 \mathrm{G}>\mathrm{A}$ \\
& rs5574 & Exon 3 & Ser68Ser \\
& rs3037354 & $5^{\prime}$ flanking region/promoter & $-883 \mathrm{TG} \mathrm{Ins} \mathrm{Del}$ \\
\hline
\end{tabular}

SNP single-nucleotide polymorphism

Data were analysed using the SPSS statistical software, version 17.0 (SPSS INC, Chicago, IL, USA).

Linkage disequilibrium (LD) between polymorphisms was analysed with Haploview (version 4.1) using the expectation-maximisation algorithm (Barrett et al. 2005).

\section{Results}

A total of 178 participants were genotyped; 88 patients in the placebo group and 90 patients in the Po-husk group.

The positions and functions of the polymorphisms selected in this study are reported in Table 1 . Table 2 summarises the genotypic and allelic distributions in the studied population. All SNPs were in Hardy-Weinberg equilibrium.

Baseline variables of patients assigned to the placebo and Po-husk groups and treatment differences between groups in CVD biomarkers presented values with the same trend as those obtained in the previous study (Solà et al. 2010)

Table 3 shows polymorphisms associated with the baseline variables. Two polymorphisms presenting a borderline significant association were also included. The rs162430 polymorphism with TG concentration $(p=0.06)$ and rs5574 polymorphism with hsCRP concentration $(p=0.08)$. The analysis of linkage disequilibrium (LD) showed that polymorphisms rs16147 and rs5574 were in high LD $\left(\mathrm{D}^{\prime}=1.0 ; \mathrm{r}^{2}=0.944\right)$, confirming previous results (Skibola et al. 2005). Because rs16147 is a promoter polymorphism with established effects on NPY gene expression (Itokawa et al. 2003), we focused our results primarily on rs16147.

Table 4 shows treatment differences between groups according to their genotypes. Polymorphism rs7799039 in the LEP gene affected the Po-husk treatment response of the TC concentration. Subjects with a GG genotype treated with Po-husk reduced their TC plasma concentration by $4.4 \%[-0.286(-0.392 ;-0.179 \mathrm{mmol} / \mathrm{L})]$, while in the placebo group, the reduction was $1.1 \%[-0.07(-0.183$; $0.043 \mathrm{mmol} / \mathrm{L})]$. The total difference between the groups was $3.3 \%(p=0.008)$. The results persisted after adjusting for multiple comparisons (adjusted $p=0.025$ ). Carriers of the allele A presented a similar response in both groups. We also identified a borderline significant association between another polymorphism in the LEP gene and Po-husk treatment response to TC concentration. Subjects with the AA genotype of rs 2167270 treated with Po-husk reduced their TC concentration by $6.4 \%[-0.420(-0.675$; $-0.164 \mathrm{mmol} / \mathrm{L})]$, while the placebo group reduced their TC concentration $0.8 \%[-0.053(-0.325 ; 0.220 \mathrm{mmol} /$ $\mathrm{L})$ ], with a total difference of $5.6 \%(p=0.06)$. Carriers of allele $\mathrm{G}$ presented similar responses in both groups.

Polymorphism rs16147 in the NPY gene was associated with an increased effect of Po-husk treatment in lowering systolic BP (sBP). Subjects with the AA genotype treated with Po-husk reduced their sBP by $5.5 \%[-7.14$ $(-11.080 ;-3.199 \mathrm{mmHg})]$, while in the placebo group, sBP levels increased by $0.7 \%$ [0.896 (-3.772; 5.564 $\mathrm{mmHg})]$, with a total difference of $6.2 \%(p=0.011)$. The results persisted after adjusting for multiple comparisons (adjusted $p=0.025$ ). Subjects carrying allele $\mathrm{G}$ presented a lower reduction in sBP levels, without significant differences with the placebo group.

Polymorphism rs16147 also affected the response of hs-CRP concentrations to treatment. Subjects with the AA genotype treated with Po-husk reduced their hs-CRP concentration by $18.5 \%[-0.437(-0.758 ;-0.117 \mathrm{mg} / \mathrm{L})]$, while in the placebo group, levels increased by $6.3 \%$, with a total difference of $24.9 \%(p=0.03)$. Carriers of the allele $\mathrm{G}$ presented similar hs-CRP concentrations in both groups, without any reduction.

We identified a borderline significant association between polymorphism rs162430 in the $P Y Y$ gene and Po-husk treatment response to TG concentration. Carriers of allele $\mathrm{T}$ treated with Po-husk reduced their triglycerides by $18.8 \%(-0.240(-0.498 ; 0.018 \mathrm{mmol} / \mathrm{L}))$, while in the placebo group, triglycerides increased by $9.2 \%(0.111$ 
Table 2 Genotypic and allelic distributions of polymorphisms

\begin{tabular}{|c|c|c|c|c|c|c|}
\hline Gene & SNP ID & Genotypes & $N(\%)$ & Allele & $F(\%)$ & $\mathrm{HWE}^{\mathrm{a}}$ \\
\hline \multirow[t]{6}{*}{$L E P$} & rs7799039 & GG & $61(34.5)$ & G & 58.2 & 0.78 \\
\hline & & GA & $84(47.5)$ & A & 41.8 & \\
\hline & & AA & $32(18.1)$ & & & \\
\hline & rs2167270 & GG & $77(43.3)$ & G & 66.3 & 0.71 \\
\hline & & GA & $82(46.1)$ & A & 33.7 & \\
\hline & & AA & 19 (10.7) & & & \\
\hline \multirow[t]{9}{*}{$P Y Y$} & rs 1058046 & GG & $75(43.1)$ & G & 64.9 & 0.70 \\
\hline & & $\mathrm{GC}$ & $76(43.7)$ & $\mathrm{C}$ & 35.1 & \\
\hline & & $\mathrm{CC}$ & $23(13.2)$ & & & \\
\hline & rs 162430 & $\mathrm{CC}$ & $141(79.2)$ & $\mathrm{C}$ & 89.0 & 0.90 \\
\hline & & $\mathrm{CT}$ & 35 (19.7) & $\mathrm{T}$ & 11.0 & \\
\hline & & TT & $2(1.1)$ & & & \\
\hline & rs2070592 & AA & $76(42.7)$ & A & 65.4 & 0.86 \\
\hline & & AG & $81(45.5)$ & G & 34.6 & \\
\hline & & GG & $21(11.8)$ & & & \\
\hline \multirow[t]{9}{*}{$N P Y$} & rs 16147 & GG & $39(22.0)$ & G & 44.9 & 0.30 \\
\hline & & GA & $81(45.8)$ & A & 55.1 & \\
\hline & & AA & $57(32.2)$ & & & \\
\hline & rs5574 & $\mathrm{CC}$ & $61(34.7)$ & $\mathrm{C}$ & 56.5 & 0.14 \\
\hline & & $\mathrm{CT}$ & $77(43.8)$ & $\mathrm{T}$ & 43.5 & \\
\hline & & TT & 38 (21.6) & & & \\
\hline & rs3037354 & InsTG & $81(45.5)$ & Ins & 66.3 & 0.46 \\
\hline & & Ins/Del & 74 (41.6) & Del & 33.7 & \\
\hline & & Del TG & $23(12.9)$ & & & \\
\hline
\end{tabular}

SNP single-nucleotide polymorphism, $H W E$ Hardy-Weinberg equilibrium, $F$ frequency

a $\chi^{2}$ test for HWE analysis

$(-0.185 ; 0.407 \mathrm{mmol} / \mathrm{L}))$, with a total difference of $28.0 \%$, although the differences between groups were not statistically significant $(p=0.08)$. Subjects with CC genotype presented a similar response in both groups, without any reduction in triglycerides concentrations.

\section{Discussion}

To our knowledge, this is the first study that reports an association between a polymorphism in the NPY gene and the beneficial effects of a soluble fibre, Po-husk, taken up through a proprietary formulation on CVD risk biomarkers.

In our study, Po-husk reduced sBP by $-7.1 \mathrm{mmHg}$ in association with the rs16147 polymorphism in the NPY gene, found in $32 \%$ of our population. Compared with the placebo group, this reduction was $-8.0 \mathrm{mmHg}$, which is twice the $-4.0 \mathrm{mmHg}$ reduction observed with Po-husk treatment without considering the gene variations (Solà et al. 2010).

The magnitude of the hypotensive effect observed in our study is clinically significant. The sBP mean net reduction with behavioural intervention that implements established recommendations (weight loss, sodium reduction, increased physical activity and limited alcohol intake) is $-3.7 \mathrm{mmHg}$, and it is $-4.3 \mathrm{mmHg}$ when patients combine the established recommendations with the Diet Approaches to Stop Hypertension (DASH; increased fruit, vegetable, and dairy intake) (Appel et al. 2003). Furthermore, the sBP reduction in $-8 \mathrm{mmHg}$ is close to that usually achieved with pharmacotherapy using $\beta$-blockers (approximately $-5 \mathrm{mmHg}$ ) or angiotensin-converting enzyme (ACE) inhibitors $(-8 \mathrm{mmHg}$ ) (Morgan et al. 2001), but without the side effects (Morgan et al. 2001).

The association between soluble fibre intake and NPY levels has heretofore not been studied. Nevertheless, several studies have shown that consumption of soluble fibre increases the production of gut peptides, including PYY (Beck 2010; Karhunen et al. 2010; Vitaglione et al. 2009). Moreover, it has been described that these peptides act in the hypothalamus by disabling NPY release (Roux and Bloom 2005; Batterham et al. 2002). Therefore, consumption of soluble fibre may be related to a decrease of NPY levels through the action of anorexigenic peptides such as PYY. 


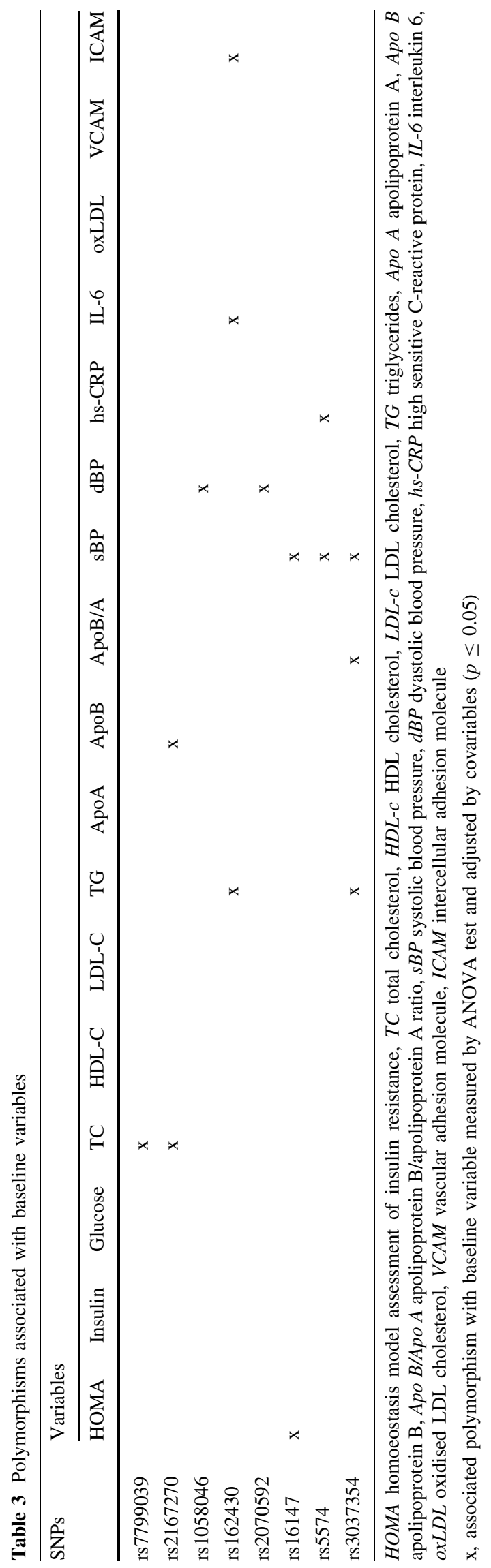

It has been proposed that $N P Y$ may play a role in the regulation of BP. For instance, Coelho et al. (2004) reported that two receptors implicated in the action of $N P Y$ are involved in the development of hypertension in rats. Furthermore, it has been shown that plasma NPY concentrations are higher in hypertensive individuals (Baltatzi et al. 2008, 2011), and a functional polymorphism in the $N P Y$ gene has been associated with hypertension (Ilveskoski et al. 2008; Bhaskar et al. 2010).

It has been shown that a putative SP1 transcription factor-binding site within the rs16147 stretch of the NPY gene sequence is lost within the rs16147 A allele (Itokawa et al. 2003), implying that this allele may demonstrate lower NPY expression levels. In accordance with this, numerous studies have observed that the rs $16147 \mathrm{G}$ allele increases NPY expression (Itokawa et al. 2003; Shah et al. 2009). Our results support a role for the $N P Y$ gene in modulating hypertension and implicate the rs16147 polymorphism in a magnified response to soluble fibre consumption on sBP, particularly in those homozygous for allele A.

The interaction observed between the NPY rs16147 polymorphism and the effect of dietary fibre intake on plasma hs-CRP concentrations is a novel finding. Compared with the placebo group, subjects homozygous for the rs16147 A allele had a $24.9 \%$ reduction in plasma hs-CRP concentration. Hs-CRP is a sensitive marker for systemic inflammation, and evidence suggests that NPY, via regulation of Y1-receptor expression on immune cells, plays a key role in inflammation (Wheway et al. 2007; Dimitrijevic et al. 2008). Other data suggest that NPY can influence the synthesis and release of pro-inflammatory cytokines and their ability to alter acetylcholine release in the brain (Das 2001). In addition, it has been hypothesised that inflammation may have a potentially important role in the development of hypertension and CRP protein levels have been associated with future development of hypertension (Sesso et al. 2003). Recently, in patients with untreated essential hypertension, increased hs-CRP and ADMA levels were associated with microalbuminuria, suggesting the involvement of inflammation and endothelial dysfunction in vascular and kidney damage (Tsioufis et al. 2010). Thus, our results might indicate that the inflammation process is involved in $\mathrm{BP}$ regulation by $N P Y$ gene variants.

Our results indicate that the beneficial effect of Po-husk intake in lowering the TC plasma concentration is variable depending on the rs7799039 polymorphism of the LEP gene. It has been shown that consumption of dietary fibre is inversely associated with plasma leptin concentrations (Kuroda et al. 2010; Murakami et al. 2007), and results from clinical studies indicate that there is a positive correlation between plasma leptin and the concentration of TC (Kastarinen et al. 2009). Several studies demonstrate that 


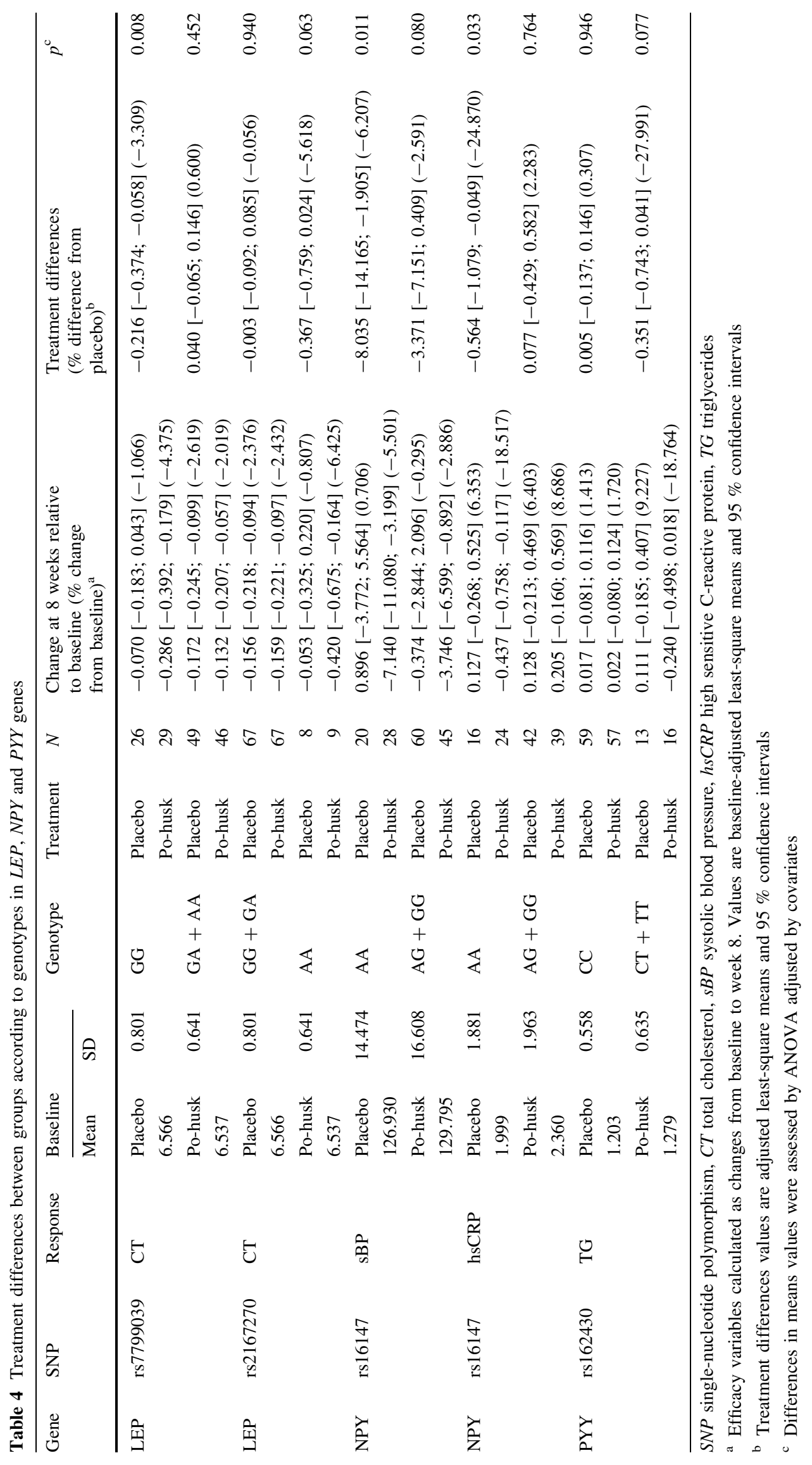


the rs7799039 polymorphism is associated with altered leptin levels (Ali et al. 2009; Yiannakouris et al. 2003). Our results suggest that the rs7799039 polymorphism in the $L E P$ gene may induce a dysfunction in the leptin-mediated signalling pathway and impair the peripheral effects of leptin on cholesterol metabolism. Although no earlier reports discuss the interactions between variants in the $L E P$ gene and dietary fibre intake, the clinical significance of our results is limited.

In this study, we identified a borderline association of the rs 162430 polymorphism in the $P Y Y$ gene with TG concentration. A reduction $(18.8 \%)$ in plasma TG was observed in carriers of allele $\mathrm{T}$ of the rs 162430 polymorphism and, compared with the placebo was $28.0 \%$. This TG reduction was $7.3 \%$ higher than the $21.7 \%$ observed with Po-husk treatment without considering gene variations (Solà et al. 2010). Furthermore, the magnitude of the TGlowering effect is clinically significant because the reduction achieved was similar to that which can be achieved by treatment with $1200 \mathrm{mg} /$ day nicotinic acid (between 17 and $26 \%$ ), an agent that has several side effects (Brunzell 2007).

It has been suggested that the hypotrigliceridaemic effect of dietary fibre intake is mediated in part by a possible delay in the absorption of triglycerides and sugars from the small intestine (Galisteo et al. 2008). The consumption of soluble fibre has been associated with increased levels of circulating PYY (Beck 2010; Karhunen et al. 2010; Vitaglione et al. 2009), and it has been shown that PYY acts to inhibit gastric mobility and acid secretion (Huda et al. 2006). Furthermore, evidence strongly suggests that PYY stimulates jejuna apolipoprotein A-IV synthesis and secretion (Tso et al. 2004; Kalogeris et al. 1998), and this apolipoprotein is involved in triglyceriderich lipoprotein metabolism (Hockey et al. 2001). In addition, PYY suppresses circulating concentrations of ghrelin (Huda et al. 2006), and several studies suggest a role of ghrelin in the regulation of lipid metabolism (Barazzoni et al. 2005; Varela et al. 2011). Finally, it has been demonstrated that PYY inhibits NPY neuronal activity, and various studies suggest that NPY plays a role in lipid metabolism (Blumenthal et al. 2002; Schwab et al. 2002). All together, the results of our study suggest that the rs162430 polymorphism in the $P Y Y$ gene may have a functional effect in altering PYY production and influencing the hypotriglyceridaemic effect of dietary fibre intake.

All in all, we propose that the beneficial effect of soluble fibre consumption on CVD risk biomarkers can be mediated in part by peripheral and central peptides the secretion of which is influenced by the consumption of soluble fibre. Concretely, the decreased levels observed in TG and TC by Po-husk intake can be mediated partly by an increase in
PYY levels and a decrease in leptin levels, respectively, after Po-husk consumption. In addition, the alteration in PYY and leptin levels by Po-husk intake may influence the release of central peptides, decreasing NPY levels and affecting BP. Moreover, we propose that functional polymorphisms in PYY, LEP and NPY genes could be responsible in part for the interindividual variation in CVD risk biomarker responses to Po-husk consumption.

In conclusion, our data provide the first evidence that polymorphisms in the $N P Y$ and $L E P$ genes can modulate the magnitude of the effects of Po-husk on CVD risk biomarkers, particularly the effects on sBP and hs-CRP plasma concentration. The screening of polymorphisms in the $N P Y$ gene, and possibly other genes related to satiety, may be useful in identifying individuals who are most likely to benefit from soluble fibre intake in the prevention of cardiovascular disease.

Acknowledgments This work was supported by ACC1Ó (CT09-10019 and TECCT10-1-0008) and grant number AGL 2008-00387/ ALI from the Spanish Government (Secretaría de Estado de Investigación del Ministerio de Ciencia e Innovación). RS received research grant support from Rottapharm/Madaus S.L. (Spain), provided directly to the Hospital Universitari Sant Joan (Reus, Spain).

Conflict of interest AA is an employee of Rottapharm/Madaus, S.L. (Spain). AC, RS, RMV and LA have not received honoraria, and all affirm that they have no conflict of interest. The funders had no role in the study design, data collection and analysis, decision to publish, or preparation of the manuscript.

\section{References}

Ali SB, Kallel A, Ftouhi B, Sediri Y, Feki M, Slimane H, Jemaa R, Kaabachi N (2009) Association of G-2548A LEP polymorphism with plasma leptin levels in Tunisian obese patients. Clin Biochem 42:584-588

Anderson J, Baird P, Davis RJ, Ferreri S, Knudtson M, Koraym A, Waters V, Williams CL (2009) Health benefits of dietary fiber. Nutr Rev 67:188-205

Appel LJ, Champagne CM, Harsha DW, Cooper LS, Obarzanek E, Elmer PJ (2003) Effects of comprehensive lifestyle modification on blood pressure control: main results of the PREMIER clinical trial. JAMA 289:2083-2093

Artiss JD, Brogan K, Brucal M, Moghaddam M, Jen KL (2006) The effects of a new soluble dietary fiber on weight gain and selected blood parameters in rats. Metabolism 55:195-202

Baltatzi M, Hatzitolios A, Tziomalos K, Iliadis F, Zamboulis C (2008) Neuropeptide Y and alpha-melanocyte-stimulating hormone: interaction in obesity and possible role in the development of hypertension. Int J Clin Pract 62:1432-1440

Baltazi M, Katsiki N, Savopoulos C, Lliadis F, Koliakos G, Hatzitolios AI (2011) Plasma neuropeptide Y (NPY) and alpha-melanocyte stimulating hormone Ia-MSH) levels in patients with or without hypertension and/or obesity: a pilot study. An J Cardiovasc Dis 1:48-59

Barazzoni R, Bosutti A, Stebel M, Cattin MR, Roder E, Visintin L, Cattin L, Biolo G, Zanetti M, Guarnieri G (2005) Ghrelin regulates mitochondrial-lipid metabolism gene expression and 
tissue fat distribution in liver and skeletal muscle. Am J Physiol Endocrinol Metab 288:E228-E235

Barrett JC, Fry B, Maller J, Daly MJ (2005) Haploview: analysis and visualization of $\mathrm{LD}$ and haplotype maps. Bioinformatics 21: 263-265

Batterham RL, Cowley MA, Small CJ, Herzog H, Cohen MA, Dakin CL, Wren AM, Brynes AE, Low MJ, Ghatei MA, Cone RD, Bloom SR (2002) Gut hormone PYY (3-36) physiologically inhibits food intake. Nature 418:650-654

Beck EJ, Tapsell LC, Batterham MJ, Tosh SM, Huang XF (2010) Oat beta-glucan supplementation does not enhance the effectiveness of an energy-restricted diet in overweight women. Br J Nutr 103: $1212-1222$

Bhaskar LV, Thangaraj K, Non AL, Praveen Kumar K, Pardhasaradhi G, Singh L, Rao VR (2010) Neuropeptide Y gene functional polymorphism influences susceptibility to hypertension in Indian population. J Hum Hypertens 24:617-622

Blumenthal JB, Andersen RE, Mitchell BD, Seibert MJ, Yang H, Herzoq H, Beamer BA, Franckowiak SC, Walston JD (2002) Novel neuropeptide Y1 and Y5 receptor gene variants: associations with serum triglyceride and high-density lipoprotein cholesterol levels. Clin Genet 62:196-202

Boey D, Sainsbury A, Herzog H (2007) The role of peptide YY in regulating glucose homeostasis. Peptides 28:390-395

Brown L, Rosner B, Willett WW, Sacks FM (1999) Cholesterollowering effects of dietary fiber: a meta-analysis. Am J Clin Nutr 69:30-42

Brunzell JD (2007) Clinical practice. Hypertriglyceridemia. N Engl J Med 357:1009-1017

Coelho EF, Ferrari MF, Maximino JR, Fior-Chadi DR (2004) Change in the expression of NPY receptor subtypes Y1 and Y2 in central and peripheral neurons related to the control of blood pressure in rats following experimental hypertension. Neuropeptides 38: $77-82$

Das UN (2001) Is obesity an inflammatory condition? Nutrition 17:953-966

Dimitrijevic M, Stanojevic S, Mitic K, Kustrimovic N, Vujic V, Miletic T, Kovacevic-Jovanovic V (2008) The anti-inflammatory effect of neuropeptide Y (NPY) in rats is dependent on dipeptidyl peptidase 4 (DP4) activity and age. Peptides 29: 2179-2187

Fernandez ML (2001) Soluble fiber and nondigestible carbohydrate effects on plasma lipids and cardiovascular risk. Curr Opin Lipidol 12:35-40

Friedewald WT, Levy RI, Fredrickson DS (1972) Estimation of the concentration of low-density lipoprotein cholesterol in plasma, without use of the preparative ultracentrifuge. Clin Chem 18: 499-502

Galisteo M, Sánchez M, Vera R, González M, Anguera A, Duarte J, Zarzuelo A (2005) A diet supplemented with husks of Plantago ovate reduces the development of endothelial dysfunction, hypertension, and obesity by affecting adiponectin and TNF- $\alpha$ in obese Zucker rats. J Nutr 135:2399-2404

Galisteo M, Duarte J, Zarzuelo A (2008) Effects of dietary fibers on disturbances clustered in the metabolic syndrome. J Nutr Biochem 19:71-84

Galisteo M, Morón R, Rivera L, Romero R, Anguera A, Zarzuelo A (2010) Plantago ovate husks-supplemented diet ameliorates metabolic alterations in obese Zucker rats through activation of AMP-activated protein kinase. Clin Nutr 29:261-267

He J, Streiffer RH, Muntner P, Krousel-Wood MA, Whelton PK (2004) Effect of dietary fiber intake on blood pressure: a randomized, double-blind, placebo-controlled trial. J Hypertens 22:73-80

Hockey KJ, Anderson RA, Cook VR, Hantgan RR, Weinberg RB (2001) Effect of the apolipoprotein A-IV Q360H polymorphism on postprandial plasma triglyceride clearance. J Lipid Res 42: 211-217

Hoffstedt J, Eriksson P, Mottagui-Tabar S, Arner P (2002) A polymorphism in the leptin promoter region (-2548 G/A) influences gene expression and adipose tissue secretion of leptin. Horm Metab Res 34:355-359

Huda MSB, Wilding JPH, Pinkney JH (2006) Gut peptides and the regulation of appetite. Obes Rev 7:163-182

Ilveskoski E, Viiri LE, Mikkelsson J, Pörsti I, Lehtimäki T, Karhunen PJ (2008) Neuropeptide Y signal peptide Pro7 substitution protects against coronary artery atherosclerosis: the Helsinki Sudden Death Study. Atherosclerosis 199:445-450

Itokawa M, Arai M, Kato S, Ogata Y, Furukawa A, Haga S, Ujike H, Sora I, Ikeda K, Yoshikawa T (2003) Association between a novel polymorphism in the promoter region of the neuropeptide $\mathrm{Y}$ gene and schizophrenia in humans. Neurosci Lett 347: 202-204

Jenkins JD, Kendall CWC, Axelsen M, Augustin LSA, Vuksan V (2000) Viscous and nonviscous fibers, nonabsorbable and low glycaemic index carbohydrates, blood lipids and coronary heart disease. Curr Opin Lipidol 11:49-56

Jequier E (2002) Leptin signalling, adiposity and energy balance. Ann NY Acad Sci 967:379-388

Kalogeris TJ, Qin XF, Chey WY, Tso P (1998) Pyy stimulates synthesis and secretion of intestinal apolipoprotein AIV without affecting mRNA expression. Am J Physiol Gastrointest Liver Physiol 275:G668-G674

Karhunen LJ, Juvonen KR, Flander SM, Liukkonen KH, Lähteenmäki L, Siloaho M, Laaksonen DE, Herzig KH, Uusitupa MI, Poutanen KS (2010) A psyllium fiber-enriched meal strongly attenuates postprandial gastrointestinal peptide release in healthy young adults. J Nutr 140:737-744

Kastarinen H, Kesaniemi YA, Ukkola O (2009) Leptin and lipid metabolism in chronic kidney failure. Scand J Clin Lab Invest 69:401-408

Kuroda M, Ohta M, Okufuji T, Takigami C, Equchi M, Hayabuchi H, Ikeda M (2010) Frequency of soup intake and amount of dietary fiber intake are inversely associated with plasma leptin concentrations in Japanese adults. Appetite 54:538-543

Lago F, Gomez R, Gomez-Reino JJ, Dieguez C, Gualillo O (2009) Adipokines as novel modulators of lipid metabolism. Trends Biochem Sci 34:500-510

Ma LJ, Tataranni PA, Hanson RL, Infante AM, Kobes S, Bogardus C, Baier LJ (2005) Variations in peptide YY and Y2 receptor genes are associated with severe obesity in Pima Indian men. Diabetes 54:1598-1602

Matthews DR, Hosker JP, Rudenski AS, Naylor BA, Treacher DF, Turner RC (1985) Homoeostasis model assessment: insulin resistance and beta-cell function from fasting plasma glucose and insulin concentrations in man. Diabetologia 28:412-419

Morgan TO, Anderson AI, MacInnis RJ (2001) ACE inhibitors, betablockers, calcium blockers, and diuretics for the control of systolic hypertension. Am J Hypertens 14:241-247

Murakami K, Sasaki S, Takahashi Y, Uenishi K, Yamasaki M, Hayabuchi H, Goda T, Oka J, Baba K, Ohki K, Watanabe R, Suqiyama Y (2007) Nutrient and food intake in relation to serum leptin concentration among young Japanese women. Nutrition 23:461-468

Queenan KM, Stewart ML, Smith KN, Thomas W, Fulcher RG, Slavin JL (2007) Concentrated oat $\beta$-glucan, a fermentable fiber, lowers serum cholesterol in hypercholesterolemic adults in a randomized controlled trial. Nutr J 6:6-14

Roux CWL, Bloom SR (2005) Peptide YY, appetite and food intake. Proc Nutr Soc 64:213-216

Salminen M, Lehtimaki T, Fan YM, Vahlberg T, Kivela SL (2008) Leucine 7 to proline 7 polymorphism in the neuropeptide $\mathrm{Y}$ gene 
and changes in serum lipids during a family-based counselling intervention among school-aged children with a family history of CVD. Public Health Nutr 11:1156-1162

Schwab US, Agren JJ, Valve R, Hallikainen MA, Sarkkinen ES, Jauhiainen M, Karvonen MK, Pesonen U, Koulu M, Uusitupa MI, Savolainen MJ (2002) The impact of the leucine 7 to proline 7 polymorphism of the neuropeptide $\mathrm{Y}$ gene on postprandial lipemia and on the response of serum total and lipoprotein lipids to a reduced fat diet. Eur J Clin Nutr 56:149-156

Sesso HD, Buring JE, Rifai N, Blake GJ, Gaziano JM, Ridker PM (2003) C-reactive protein and the risk of developing hypertension. JAMA 290:2945-2951

Shah SH, Freedman NJ, Zhang LS, Crosslin DR, Stone DH, Haynes C, Johnson J, Nelson S, Wang L, Connelly JJ, Muehlbauer M, Ginsburg GS, Crossman DC, Jones CJ, Vance J, Sketch MH, Granger CB, Newgard CB, Gregory SG, Goldschmidt-Clermont PJ, Kraus WE, Hauser ER (2009) Neuropeptide Y Gene Polymorphisms Confer Risk of Early-Onset Atherosclerosis. PLoS Genet 5:1-10

Sierra M, García JJ, Fernández N, Diez MJ, Calle AP, Farmafibra Group (2002) Therapeutic effects of psyllium in type 2 diabetic patients. Eur J Clin Nutr 56:830-842

Simopoulos AP (2010) Nutrigenetics/nutrigenomics. Annu Rev Public Health 31:53-68

Skibola DR, Smith MT, Bracci PM, Hubbard AE, Agana L, Chi S, Holly EA (2005) Polymorphisms in ghrelin and neuropeptide $Y$ genes are associated with non-Hodgkin lymphoma. Cancer Epidemiol Biomarkers Prev 14:1251-1256

Solà R, Godas G, Ribalta J, Vallvé JC, Girona J, Anguera A, Ostos M, Recalde D, Salazar J, Caslake M, Martín-Luján F, Salas-Salvadó J, Masana L (2007) Effects of soluble fiber (Plantago ovata husk) on plasma lipids, lipoproteins, and apolipoproteins in men with ischemic heart disease. Am J Clin Nutr 85:1157-1163

Solà R, Bruckert E, Valls RM, Narejos S, Luque X, Castro-Cabezas M, Doménech G, Torres F, Heras M, Farrés X, Vaquer JV, Martínez JM, Almaraz MC, Anguera A (2010) Soluble fibre (Plantago ovata husk) reduces plasma low-density lipoprotein (LDL) cholesterol, triglycerides, insulin, oxidised LDL and systolic blood pressure in hypercholesterolaemic patients: a randomised trial. Atherosclerosis 211:630-637

Theuwissen E, Mensink RP (2008) Water-soluble dietary fibers and cardiovascular disease. Physiol Behav 94:285-292

Torekov SS, Larsen LH, Glumer C, Borch-Johnsenk K, Jorgensen T, Holst JJ, Madsen OD, Hansen T, Pedersen O (2005) Evidence of an association between the Arg72 allele of the peptide YY and increased risk of type 2 diabetes. Diabetes 54:2261-2265

Torres N, Guevara-Cruz M, Granados J, Vargas-Alarcón G, Gonzálex-Palacios B, Ramos-Barragan VE, Quiroz-Olquín G, Flores-
Islas IM, Tovar AR (2009) Reduction of serum lipids by soy protein and soluble fiber is not associated with the ABCG5/G8, apolipoprotein $\mathrm{E}$, and apolipoprotein A1 polymorphisms in a group of hyperlipidemic Mexican subjects. Nutr Res 29:728-735

Tsioufis C, Dimitriadis K, Andrikou E, Thomopoulos C, Tsiachris D, Stefanadi E, Mihas C, Miliou A, Papademetriou V, Stefanadis C (2010) ADMA, C-reactive protein, and albuminuria in untreated essential hypertension: a cross-sectional study. Am J Kidney Dis 55:1050-1059

Tso P, Sun W, Liu M (2004) Gastrointestinal satiety signals-IV. Apolipoprotein A-IV. Am J Physiol Gastrointest Liver Physiol 286:G885-G890

Ukkola OH, Puurunen VP, Piira OP, Niva JT, Lepojärvi ES, Tulppo MP, Huikuri HV (2011) High serum fasting peptide YY (3-36) is associated with obesity-associated insulin resistance and type 2 diabetes. Regul Pept 170:38-42

Varela L, Vázquez MJ, Cordido F, Nogueiras R, Vidal-Puig A, Diéguez C, López M (2011) Ghrelin and lipid metabolism: key partners in energy balance. J Mol Endocrinol 46:43-63

Vitaglione P, Lumaga RB, Stanzione A, Scalfi L, Fogliano V (2009) beta-Glucan-enriched bread reduces energy intake and modifies plasma ghrelin and peptide YY concentrations in the short term. Appetite 53:338-344

Vuksan V, Jenkins AL, Rogovik AL, Fairgrieve CD, Jovanovski E, Leiter LA (2011) Viscosity rather than quantity of dietary fibre predicts cholesterol-lowering effect in healthy individuals. Br J Nutr 106:1349-1352

Wheway J, Herzog H, Mackay F (2007) NPY and receptors in immune and inflammatory diseases. Curr Top Med Chem 7: $1743-1752$

Wu K, Bowman R, Welch AA, Luben RN, Wareham N, Khaw KT, Bingham SA (2007) Apolipoprotein E polymorphisms, dietary fat and fibre, and serum lipids: the EPIC Norfolk study. Eur Heart J 28:2930-2936

Yiannakouris N, Melistas L, Yannakoulia M, Mungal K, Mantzoros CS (2003) The -2548G/A polymorphism in the human leptin gene promoter region is associated with plasma free leptin levels; interaction with adiposity and gender in healthy subjects. Hormones 2:229-236

Young SA, Hung SC, Anderson WH, Albers DR, Langhorst ML, Yokoyama W (2012) Effects of cationic hydroxyethyl cellulose on glucose metabolism and obesity in a diet-induced obesity mouse model. J Diabetes 4:85-94

Ziai SA, Larijani B, Akhoondzadeh S, Fakhrzadeh H, Dastpak A, Bandarian F, Rezai A, Badi HN, Emami T (2005) Psyllium decreased serum glucose and glycosylated haemoglobin significantly in diabetic outpatients. J Ethnopharmacol 102:202-207 